\title{
Non-chemical alternatives to methyl bromide against Ephestia cautella (Lepidoptera: Pyralidae): microwave and ozone
}

\author{
M.M. Abo-El-Saad ${ }^{1}$, H.A. Elshafie ${ }^{2}$, A.M. Al Ajlan ${ }^{3}$ and I.A. Bou-Khowh ${ }^{4}$ \\ Date Palm Research Center of Excellence ${ }^{1,2,4}$, College of Agricultural and Food Sciences ${ }^{3}$, \\ King Faisal University, Al-Hassa 31982, P.O. Box 400, Saudi Arabia \\ Corresponding author: M. M. Abo-El-Saad, professor; research field: insect toxicology;
}

\begin{abstract}
:
Multiple microwave power (MP) has been applied against Ephestia cautella (Walker) at various exposure times. Five seconds exposure time at various MP up to $60 \%$ had no effect on insect mortality, by increasing the MP up to $100 \%$, the mortality reached $20 \%$ for larvae and $33 \%$ for adults. When exposure time was increased to 15 seconds with different MP, mortality reached $100 \%$ and $80 \%$ at $60 \%$ power for adults and larvae, respectively. Eggs of E. cautella were exposed to various MP at different time; the hatchability reached $0.0 \%$ after 10 and 15 seconds at $100 \%$ MP. Data showed microwave had no effect on soluble proteins isolated from dates treated by microwave at various time up to 15 seconds, and had no effect on protein pattern on sodium dodecyl sulfate polyacrylamide gel electrophoresis (SDS-PAGE). Ozonation with $2.0 \mathrm{ppm}$ ozone generated with various time 4,8 and 12 hours, gave $28 \%, 73 \%$, and $83 \%$ mortality against adults, while it gave $10 \%, 20 \%$ and $27 \%$ mortality against larvae. Ozone exhibited less effect against pupae and eggs hatchability. The possibility of using microwave and ozone in integrated management program against stored product pests is discussed.
\end{abstract}

Key words: methyl bromide, microwave, ozone, Ephestia cautella, Phoenix dactylifera

\section{INTRODUCTION}

Date palm, Phoenix dactylifera, is the most common cultivated tree throughout the Middle East and the kingdom of Saudi Arabia, which is one of the largest producers of dates in the world with dates production reached 986,000 tonnes in 2008 (AOAD, 2009). There are huge losses in food storage and its quantity by warehouse insects; amongst the Ephestia cautella, which create a center of attention to many researchers of its economic importance. In fact with its physiological adaptability is one of the most destructive insect of stored materials such as dried fig, wheat-flour, chocolate dried fruits, nuts, grain and dates (Singh and Moore, 1985). Larvae cause considerable damage by feeding and/or by contaminating stored food with dead bodies and their own products, e.g. excreta, webbing, silk and feces while no damage from adults as they feed on liquid food and/or do not feed at all, in contrast their bodies can become undesirable. Yet, stored product pest control is depending almost entirely on pesticides and fumigants; two universally available fumigants are remaining for disinfestations of durable commodities, namely, methyl bromide (MB) and phosphine (PH3); each has its own limitations. MB is facing a phase-out worldwide by the year 2015 under the terms of the Montreal Protocol (UNEP, 1999). Recently, many researchers have been devoted for seeking an alternative to $M B$ against insect pests in warehouses such as microwave and ozone as non-chemical methods.

Microwave heating is based on the transformation of alternating electromagnetic field energy into thermal energy by affecting polar molecules of a material. All matter is made up of atoms and molecules and some of these molecules are electrically neutral but many are bipolar. When an electric field is applied, the bipolar molecules tend to behave like microscopic magnets and attempt to align themselves with the field. When the electrical field is changing millions of times per second (915 or 2450 million times per second), these molecular magnets are unable to keep up the forces acting to slow them. This resistance to the rapid movement of the bipolar molecules creates friction and results in heat dissipation in the material exposed to the microwave radiation (Brygidyr, 1977). This electromagnetic energy interacts directly with the commodity's interior to quickly raise the center temperature (Tang et al., 2000; Wang et al., 2001a; 2001b). Therefore, an 
effective way of killing insects of all kinds is to elevate their body temperature above a certain lethal value using microwave energy (Tilton, 1987). There has been an increasing interest in using radio frequency (RF) and microwave energies as a thermal treatment method for postharvest insect control in agricultural commodities (Tang et al., 2000). Microwave radiation and conductive heating were used to completely kill adult Tribolium castaneum (Coleoptera: Tenebrionidae) in wheat flour to protect the flour during storage without significantly effecting its quality ( Lu et al., 2010a).

Efficacy of ozone has been evaluated to control pests of stored grain. Ozone is attractive because its degradation product is oxygen, thus leaving no undesirable residue, and ozone can be generated onsite, eliminating the need to store or dispose of chemical containers. Previously, it has been reported 92-100\% mortality of adult maize weevils, Sitophilus zeamais (Motschulsky), larvae of Indian meal moth, Plodia interpunctella (Hubner), and adult red flour beetles, $T$. castaneum (Herbst) in infested maize when fumigated with $50 \mathrm{ppm}$ ozone for $3 \mathrm{~d}$ (Kells et al., 2001). Isikber and Öztekin (2009) found in generally that Tribolium confusum was more tolerant to ozone treatment than Ephestia kuehniella. Ozone flush treatment at 3D-min intervals for $5 \mathrm{~h}$ resulted in almost complete mortality of all life stages of $E$. kuehniella placed in the top position of $2 \mathrm{~kg}$ wheat, whereas eggs of $E$. kuehniella placed in the bottom position of $2 \mathrm{~kg}$ wheat were hard to kill. For $T$. confusum, larvae placed in the bottom position of 2 $\mathrm{kg}$ wheat were easily killed, whereas eggs, pupae and adults survived.

Dates production is about 5.4 million metric tonnes (Mt) in 2001 and increased to 6.7 million Mt in 2004. Dates are produced largely in hot arid regions of South West Asia and North Africa; marketed all over the world as a high-value confectionery and remaining an extremely important subsistence crop in most of the desert regions (Botes and Zaid, 2002). The objective of this study was focused on using microwave and ozone to replace the use of methyl bromide for controlling $E$. cautella as a major insect pest in dates' warehouses in Saudi Arabia as well as in several Arabian countries, where the annual production is over 5 million tonnes.

\section{MATERIALS AND METHODS}

Equipment: Laboratory Processing Microwave BP310/50 was purchased from Microwave Research and Application Inc. (MRA), USA and Ozone
Generator XT-6000S was purchased from Air-Zone ${ }^{\circledR}$ Inc., USA. Ozone Sensor Model A-21Zx, S/N: 74930 was purchased from EcoSenso ${ }^{T M}$ Inc. USA, the instrument was calibrated in the facilities of the company according to the standard procedures. This instrument can reads from 0.01 to over $10 \mathrm{ppm}$ of ozone.

Insect: Ephestia cautella (Walker) (Lepidoptera: Pyralidae) was reared at insect laboratory, Date Palm Research Center, King Faisal University, Hofuf, Saudi Arabia.

Insect culture technique (rearing): Ephestia cautella was successfully reared in laboratory cultures on standard diet composed of a mixture of a half part of crushed date fruit, one part barley, one and a half parts of broiler feed and one and a half parts layer feed (by weight) as described by Al-Azab, (2007). The sterilized diet was mixed with $400 \mathrm{ml}$ of glycerol. Newly emerged male and female adults were paired in wooden cage with screen sides. A piece of white paper was put under the cage to collecting eggs, which fell through the wire mesh, then transferred to Petri dishes. Fifteen mg eggs of $E$. cautella were checked under microscope to remove any parasited eggs, then transferred into one liter glass jar containing $200 \mathrm{gm}$ of the previous sterilized diet. The glass jar was covered with a layer of cheesecloth and placed in an incubator with 50-60\% relative humidity, at $29 \pm 1^{\circ} \mathrm{C}$ with $12 \mathrm{~L}: 12 \mathrm{D}$.

Chemicals: All chemical compounds were purchased from Sigma-Aldrich ${ }^{\circledR}$ Co., USA.

Exposure of different stages of $E$. cautella to various microwave energy: Various microwave power of $10,20,30,40,50,60,70,80,90$ and $100 \%$ of $2450 \mathrm{MHz}$ against $E$. cautella in different stages; eggs, larvae, and adults were performed according to Baysal et al., (1998) as follows: Ten infested dates with 10 larvae (10 days old), ten adults (one day old), and twenty eggs loaded on two dates, were placed on Petri dishes (9 $\mathrm{mm}$ diameter) for each replicate. Three replicates were exposed to various microwave power for different intervals $0,5,10,15$, seconds. Non-exposed replicates were used as control. Mortality of larvae and adults were calculated based on method of Finney (1971). In the case of eggs, treatments were kept in an incubator with the same conditions as mentioned before for two weeks, then hatchability percentage was calculated.

Exposure of different stages of $E$. cautella to ozone:Ozone application was carried out in a flexible plastic tube $(r=5,25 \mathrm{~cm} \times 234 \mathrm{~cm}$ length) connected 
with Air-Ozone generator. The insect stages, larvae and adults were taken with $5 \mathrm{~g}$ standard medium and then placed in plastic cages $(8 \mathrm{~cm}$ width $\times 8 \mathrm{~cm}$ length $\times 12 \mathrm{~cm}$ height) were made from a fine mesh cloth allowing free gas to flow and to prevent insect escaping. Eggs were placed in open Petri dishes for fumigation. The experiment was carried out in three replicates, each with 10 non-sexed adult (1-2 days old), 10 larvae (10 days old), and 20 eggs (Newly- 1 day old). Ozone gas was applied at concentration of 2.0 ppm (Ozone concentration from ozone generator was measured using ozone sensor calibrator) against different stages of $E$. cautella for various discontinuous exposure times (10 seconds/min) 0,2 , 4, 6, 8 and 12 hours. Non-exposed replicates were used as control. Mortality and hatchability were calculated based on methods of Finney (1971).

Isolation of soluble proteins from treated dates by microwave energy: Three replicates-twenty fives gram of dates have been exposed to microwave energy at $2450 \mathrm{MHz}$ for 5, 10, and 15 seconds, then soaked in $20 \mathrm{mM}$ Tris- $\mathrm{HCl}$ buffer $\mathrm{pH} 8.0$ for overnight at room temperature. Dates were homogenized in 80 $\mathrm{ml}$ of the same buffer electrical blender. The homogenates were filtered through double layer of cheesecloth, and then centrifuged at $14000 \mathrm{rpm}$ for 5 $\min$. at $-4^{\circ} \mathrm{C}$. The pellets were discarded and the clear supernatants were kept at $5^{\circ} \mathrm{C}$ after adding $0.02 \%$ sodium azide as antimicrobial agent until used for protein determination and protein pattern analysis.

Protein determination: The protein was determined according to Bradford (1976) assay method.

SDS-gel electrophoresis: Electrophoresis was performed as described by Laemmli (1970). Small amount of soluble proteins from dates $40 \mu \mathrm{g}$, was mixed with SDS-sample buffer, boiled at $95^{\circ} \mathrm{C}$ for 4 minutes. The boiled samples were cooled and loaded onto $12 \%$ polyacrylamide gel that was run at constant current, $30 \mathrm{mAs}$. The run was terminated after the blue dye reached to the bottom and the gel was removed from the glass plate sandwich. The gel was stained for $30 \mathrm{~min}$. at room temperature in staining solution contains (50\% methanol, $10 \%$ acetic acid and $0.011 \%$ coomassie blue R- 250). After $30 \mathrm{~min}$, the gel was removed from the staining solution, rinsed with distilled water and placed in distaining solution contains (10\% methanol and $7.5 \%$ acetic acid).

Statistical analysis: Data were analyzed using MINITAB Statistical software, version 13.30, Copyright 2000, Minitab Inc. and means were compared by Duncan's multiple range tests in $5 \%$ level.

\section{RESULTS:}

Effect of microwave on $E$. cautella: Adjustable microwave power has been applied against $E$. cautella eggs, larvae and adults. Total power of microwave is $2450 \mathrm{MHz}$, different power ranged from $10 \%$ up to $100 \%$ (from total power) were used at various exposure times to figure out the optimum microwave power against E. cautella. Figure (I) showed that maximum percent mortality reached $20 \%$ and $33 \%$ against larvae and adults respectively for 5 seconds exposure time at 100\% microwave power (MP). By increasing the time to 10 seconds as shown in Figure (I), percent mortality increased to reach $40 \%$ and $77 \%$ at $80 \% \mathrm{MP}, 80 \%$ and $97 \%$ at $100 \%$ MP against larvae and adults, respectively. One hundred percent mortality was reached by increasing the exposure time to 15 seconds at $90 \%$ MP as shown in Figure (I). Microwave effect on eggs hatchability of $E$. cautella was extended to see whether or not microwave could affect eggs hatchability at various exposure times. Figure (II) clearly indicated that 5 seconds exposure time was revealed a little effect on eggs hatchability even at maximum MP. By increasing the time to 10 and 15 seconds, the hatchability was decreased to reach approximately $4 \%$ for 10 and 15 seconds. The LC $_{50}$ and $\mathrm{LC}_{95}$ values of microwave effect against $E$. cautella are shown in Table (I). The data indicated that $E$. cautella eggs were more sensitive to microwave when exposed to 15 seconds when compared with larvae and adults. At this period of time, $\mathrm{LC}_{50}$ and $\mathrm{LC}_{95}$ values were 1.1, 53.76 and $43.76 \%$ and $180.50,75.82$ and $54.85 \%$ for eggs, larvae and adults, respectively. The 95\% feducial limits of the $\mathrm{LC}_{50}$ values at the same period of time were ( 0.02 and 3.96), (49.32 and 57.2\%) and (40.98 and 64.02\%) for eggs, larvae and adults, respectively. The $L T_{50}$ and $L T_{95}$ values of microwave power against all stages of $E$. cautella are presented in Table (II). The data showed that when eggs were exposed to various microwave power, the lethal time values were significantly decreased by increasing MP; however, the decreasing rate was less in the case of larvae and adults. The $\mathrm{LT}_{50}$ values at 50 and 100\% MP were 8.56 and 6.39 seconds for eggs with 95\% fiducial limits (7.56-9.40, and 5.45-7.17) and 14.62 and 7.48 seconds for larvae with $95 \%$ fiducial limits (13.20-17.02, and 6.0-8.62) and 12.96 and 5.85 seconds for adults with 95\% fiducial limits (11.8013.75, and 4.33-6.99). 
Table 1: $\mathrm{LC}_{50}$ and $\mathrm{LC}_{95}$ values of microwave effects on different stages of $E$. cautella after exposing to various periods of time.

\begin{tabular}{|c|c|c|c|c|c|c|c|}
\hline $\begin{array}{c}\text { Time } \\
\text { (seconds) }\end{array}$ & Stage & $\begin{array}{c}\mathrm{LC}_{50}(\%) \\
\text { ( 95\% fiducial limits) }\end{array}$ & $\begin{array}{c}\mathrm{LC}_{95}(\%) \\
\text { ( 95\% fiducial limits) }\end{array}$ & $\begin{array}{l}\text { Chi square } \\
\left(X^{2}\right)\end{array}$ & $\begin{array}{l}\text { Degrees of } \\
\text { freedom }\end{array}$ & $\begin{array}{l}\text { Slope } \\
\pm \text { SE }\end{array}$ & $P$ \\
\hline 5 & \multirow{3}{*}{ Egg } & $\begin{array}{c}111.96 \\
(103.71-129.21)\end{array}$ & $\begin{array}{c}144.94 \\
(126.48-191.67)\end{array}$ & 6.44 & 8 & $5.67 \pm 1.04$ & 0.60 \\
\hline 10 & & $\begin{array}{c}24.99 \\
(21.63-28.05) \\
\end{array}$ & $\begin{array}{c}68.20 \\
(62.0-76.34)\end{array}$ & 24.15 & 8 & $1.46 \pm 0.11$ & 0.01 \\
\hline 15 & & $\begin{array}{c}1.1 \\
(0.02-3.96)\end{array}$ & $\begin{array}{c}180.50 \\
(102.84-859.51)\end{array}$ & 4.26 & 8 & $0.29 \pm 0.07$ & 0.83 \\
\hline 5 & \multirow{3}{*}{ Larva } & $\begin{array}{c}109.05 \\
(101.65-243.42)\end{array}$ & $\begin{array}{c}123.12 \\
(109.21-599.18)\end{array}$ & 1.10 & 1 & $12.06 \pm 5.33$ & 0.29 \\
\hline 10 & & $\begin{array}{c}81.84 \\
(77.59-86.07) \\
\end{array}$ & $\begin{array}{c}110.54 \\
(102.68-124.1) \\
\end{array}$ & 7.5 & 5 & $4.78 \pm 0.65$ & 0.19 \\
\hline 15 & & $\begin{array}{c}53.76 \\
(49.32-57.2)\end{array}$ & $\begin{array}{c}75.82 \\
(71.14-82.97)\end{array}$ & 13.7 & 4 & $4.26 \pm 0.57$ & 0.01 \\
\hline 5 & \multirow{3}{*}{ Adult } & $\begin{array}{c}110.82 \\
(99.44-157.16)\end{array}$ & $\begin{array}{c}151.29 \\
(122.63-331.35)\end{array}$ & 2.52 & 3 & $4.70 \pm 1.42$ & 0.47 \\
\hline 10 & & $\begin{array}{c}68.7 \\
(64.24-72.48)\end{array}$ & $\begin{array}{c}97.49 \\
(91.36-106.91)\end{array}$ & 8.80 & 5 & $4.18 \pm 0.50$ & 0.12 \\
\hline 15 & & $\begin{array}{c}43.76 \\
(40.98-46.02)\end{array}$ & $\begin{array}{c}54.85 \\
(51.54-60.48)\end{array}$ & 6.89 & 4 & $6.42 \pm 1.0$ & 0.14 \\
\hline
\end{tabular}

Table 2: $\mathrm{LT}_{50}$ and $\mathrm{LT}_{95}$ values of various microwave powers on different stages of $E$. cautella.

\begin{tabular}{|c|c|c|c|c|c|c|c|}
\hline MP \% & Stage & $\begin{array}{c}\mathrm{LT}_{50} \text { (second) } \\
\text { ( } 95 \% \text { fiducial limits) }\end{array}$ & $\begin{array}{c}\mathrm{LT}_{95} \text { (second) } \\
\text { ( 95\% fiducial limits) }\end{array}$ & $\begin{array}{c}\text { Chi } \\
\text { square } \\
\left(\mathrm{X}^{2}\right)\end{array}$ & $\begin{array}{l}\text { Degrees of } \\
\text { freedom }\end{array}$ & $\begin{array}{l}\text { Slope } \\
\pm S E\end{array}$ & $P$ \\
\hline 50 & \multirow{6}{*}{ Egg } & $\begin{array}{c}8.56 \\
(7.56-9.40) \\
\end{array}$ & $\begin{array}{c}14.53 \\
(13.28-16.32) \\
\end{array}$ & 38.49 & 1 & $2.77 \pm 0.32$ & $<0.001$ \\
\hline 60 & & $\begin{array}{c}8.35 \\
(7.33-9.21)\end{array}$ & $\begin{array}{c}14.62 \\
(13.32-16.50)\end{array}$ & 48.99 & 1 & $2.62 \pm 0.30$ & $<0.001$ \\
\hline 70 & & $\begin{array}{c}7.68 \\
(6.63-8.57)\end{array}$ & $\begin{array}{c}14.39 \\
(12.98-16.51)\end{array}$ & 35.48 & 1 & $2.33 \pm 0.28$ & $<0.001$ \\
\hline 80 & & $\begin{array}{c}7.68 \\
(6.63-8.57) \\
\end{array}$ & $\begin{array}{c}14.39 \\
(12.98-16.51)\end{array}$ & 35.48 & 1 & $2.33 \pm 0.28$ & $<0.001$ \\
\hline 90 & & $\begin{array}{c}6.60 \\
(5.36-7.59)\end{array}$ & $\begin{array}{c}15.11 \\
(13.16-18.50)\end{array}$ & 17.01 & 1 & $1.77 \pm 0.24$ & $<0.001$ \\
\hline 100 & & $\begin{array}{c}6.39 \\
(5.45-7.17)\end{array}$ & $\begin{array}{c}11.84 \\
(10.61-13.76)\end{array}$ & 15.56 & 1 & $2.37 \pm 0.29$ & $<0.001$ \\
\hline 50 & \multirow{6}{*}{ Larva } & $\begin{array}{c}14.62 \\
(13.20-17.02)\end{array}$ & $\begin{array}{c}20.28 \\
(17.30-32.38)\end{array}$ & 0.24 & 1 & $4.48 \pm 1.24$ & 0.63 \\
\hline 60 & & $\begin{array}{c}13.05 \\
(11.85-13.95)\end{array}$ & $\begin{array}{c}16.60 \\
(15.36-19.28)\end{array}$ & 0.07 & 1 & $6.1 \pm 1.30$ & 0.79 \\
\hline 70 & & $\begin{array}{c}12.56 \\
(11.37-13.43) \\
\end{array}$ & $\begin{array}{c}15.99 \\
(14.87-18.13) \\
\end{array}$ & 0.09 & 1 & $6.1 \pm 1.19$ & 0.77 \\
\hline 80 & & $\begin{array}{c}11.0 \\
(9.76-11.98)\end{array}$ & $\begin{array}{c}15.13 \\
(13.83-17.45)\end{array}$ & 0.83 & 1 & $4.60 \pm 0.82$ & 0.36 \\
\hline 90 & & $\begin{array}{c}7.48 \\
(6.0-8.62)\end{array}$ & $\begin{array}{c}13.52 \\
(11.70-17.06)\end{array}$ & 0.63 & 1 & $2.47 \pm 0.44$ & 0.43 \\
\hline 100 & & $\begin{array}{c}7.48 \\
(6.0-8.62)\end{array}$ & $\begin{array}{c}13.53 \\
(11.70-17.60)\end{array}$ & 0.63 & 1 & $2.47 \pm 0.44$ & 0.43 \\
\hline 50 & \multirow{6}{*}{ Adult } & $\begin{array}{c}12.96 \\
(11.80-13.75)\end{array}$ & $\begin{array}{c}15.83 \\
(14.90-17.56)\end{array}$ & 0.02 & 1 & $7.33 \pm 1.5$ & 0.89 \\
\hline 60 & & $\begin{array}{c}10.50 \\
(9.31-11.44)\end{array}$ & $\begin{array}{c}14.32 \\
(13.07-16.50)\end{array}$ & 0.98 & 1 & $4.72 \pm 0.83$ & 0.32 \\
\hline 70 & & $\begin{array}{c}9.12 \\
(7.76-10.20) \\
\end{array}$ & $\begin{array}{c}14.46 \\
(12.80-17.66)\end{array}$ & 0.02 & 1 & $3.18 \pm 0.57$ & 0.94 \\
\hline 80 & & $\begin{array}{c}7.64 \\
(6.14-8.79)\end{array}$ & $\begin{array}{c}13.81 \\
(11.94-17.52)\end{array}$ & 0.23 & 1 & $2.47 \pm 0.45$ & 0.63 \\
\hline 90 & & $\begin{array}{c}7.48 \\
(6.0-8.62) \\
\end{array}$ & $\begin{array}{c}13.52 \\
(11.70-17.06) \\
\end{array}$ & 0.63 & 1 & $2.47 \pm 0.44$ & 0.43 \\
\hline 100 & & $\begin{array}{c}5.85 \\
(4.33-6.99) \\
\end{array}$ & $\begin{array}{c}11.79 \\
(9.99-15.25) \\
\end{array}$ & 5.52 & 1 & $2.09 \pm 0.39$ & 0.02 \\
\hline
\end{tabular}




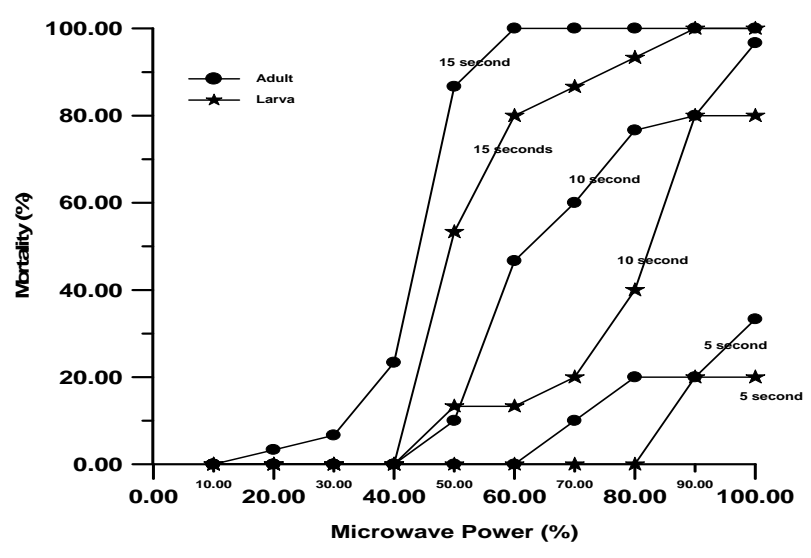

Fig. 1: Relationship between mortality of $E$. cautella (larvae and adults) and different microwave power at various exposure times.

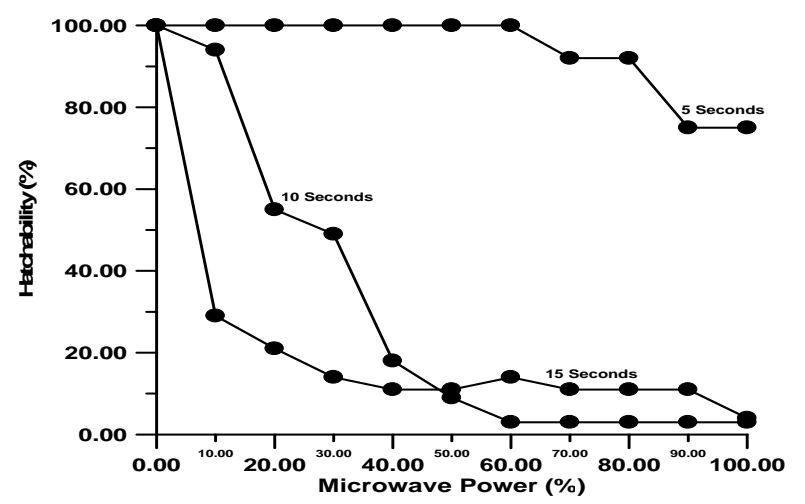

Fig. 2: Relationship between Egg hatchability of $E$. cautella and different microwave power at various exposure times.

Effect of microwave on soluble protein isolated from dates has been exposed to microwave for various exposure times: Soluble proteins from dates exposed to microwave for different exposure times were isolated and determined colormetrically based on method of Bradford (1976). Fig. (III) showed that microwave energy had no effect on the soluble proteins isolated from treated and non-treated dates. The data showed the concentration of soluble proteins in non-treated dates was $0.876 \mathrm{mg} / \mathrm{ml}$, whereas in treated dates for 5,10 , and 15 seconds was $0.876 \mathrm{mg} / \mathrm{ml}, 0.872 \mathrm{mg} / \mathrm{ml}$, and $0.877 \mathrm{mg} / \mathrm{ml}$, respectively. Based on these results, could be generally concluded that microwave energy had no effect on soluble protein in date cell when it exposed to the microwave up to $100 \%$ MP which equivalent to $2450 \mathrm{MHz}$. For more emphasis on this finding, the analysis was extended by using SDS-polyacrylamide gel electrophoresis (Fig. IV) to analyze the protein pattern for each exposure time of dates to microwave energy. The gel exhibited that protein bands for each treatment are similar, i.e. no degradation of proteins has been observed, and subsequently microwave energy had no effects on protein profile.

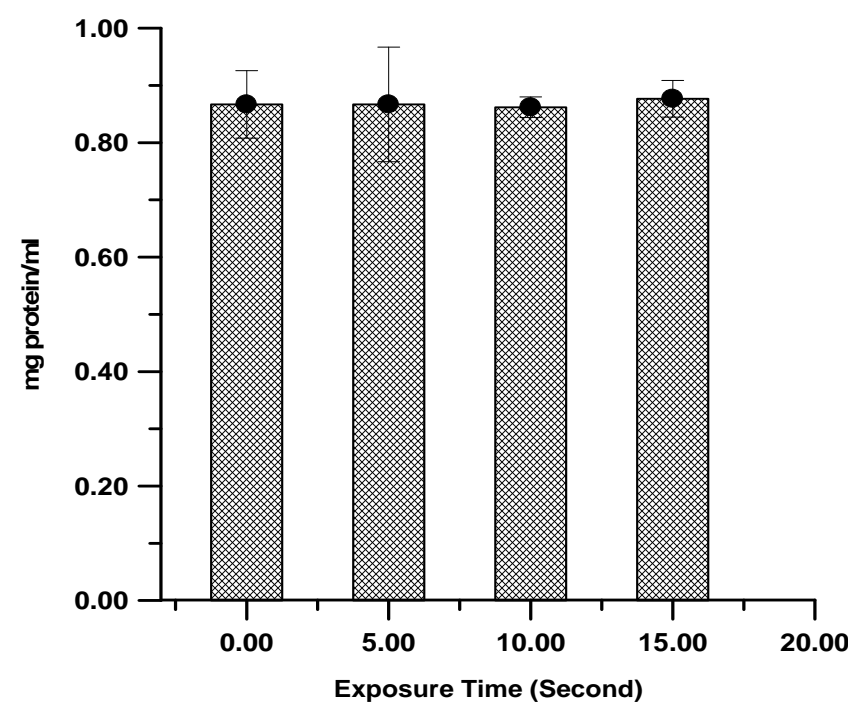

Fig. 3: Soluble proteins isolated from dates have been treated with microwave at maximum power $(2450 \mathrm{MHz}$.) for various exposure times.

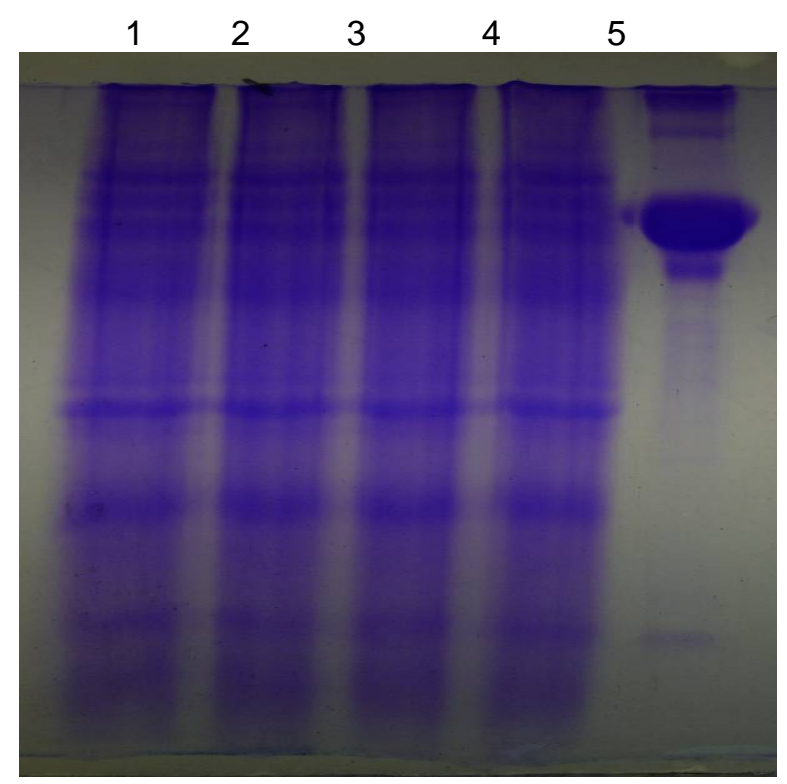

Fig. 4: SDS-polyacrylamide gel electrophoresis analysis of soluble proteins isolated from dates treated by microwave at maximum power for various exposure times, control (lane 1), 5 seconds exposure time (lane 2), 10 seconds (lane 3 ) and 15 seconds (lane 4), and lane 5; standard protein marker. 
Effect of microwave energy on the sugar profile of treated dates: Samples of dates have been exposed to microwave energy at maximum power for various exposure times 5,10 , and 15 seconds were extracted as described under material and methods, then, clear supernatant was analyzed by HPLC. The data in Fig. (V) showed that sugar content in untreated samples were almost very close to treated samples, where fructose, glucose, and sucrose concentration in untreated samples were 9.32, 9.44 and $0.09 \%$, respectively. In treated samples at maximum microwave power for 15 seconds no significant effect had observed, where fructose, glucose, and sucrose concentration in treated samples were $9.55,9.74$ and $0.09 \%$, respectively.

Effect of ozone on different stages of $E$. cautella: Different stages of the insect were exposed to 2.0 ppm of ozone at various exposure times 2, 4, 8, and
12 hours. The data in Fig. (VI) clearly showed that adults mortality of $E$. cautella was increased by increasing exposure times to ozone, reaching near $90 \%$ after 12 hours exposure time. Larvae were less sensitive to ozone than adults, where at the exposure time 12 hours, mortality was approximately 30\% (Fig. VII). When pupae were exposed to ozone, percent emergence was reached $50 \%$ after 12 hours exposure time (Fig. VIII). Eggs hatchability that have been exposed to ozone for 12 hours was 90\% indicating that ozone had very little effect on egg hatchability (Fig. IX). Table (III) showed that The $\mathrm{LT}_{50}$ values of ozone at $2.0 \mathrm{ppm}$ on egg, larva and adult of $E$. cautella were, 6.65, 19.27 and 14.30 second with 95\% fiducial limits (5.47-7.72, 12.61172.21, and 12.32-20.07) whereas, $\mathrm{LT}_{95}$ values were $13.99,52.88$ and 26.29 second, respectively with $95 \%$ fiducial limits $(11.65-18.80,24.11-391.45$, and 19.22-55.34).

Table 3: $\mathrm{LT}_{50}$ and $\mathrm{LT}_{95}$ values of ozone at $2.0 \mathrm{ppm}$ on different stages of $E$. cautella.

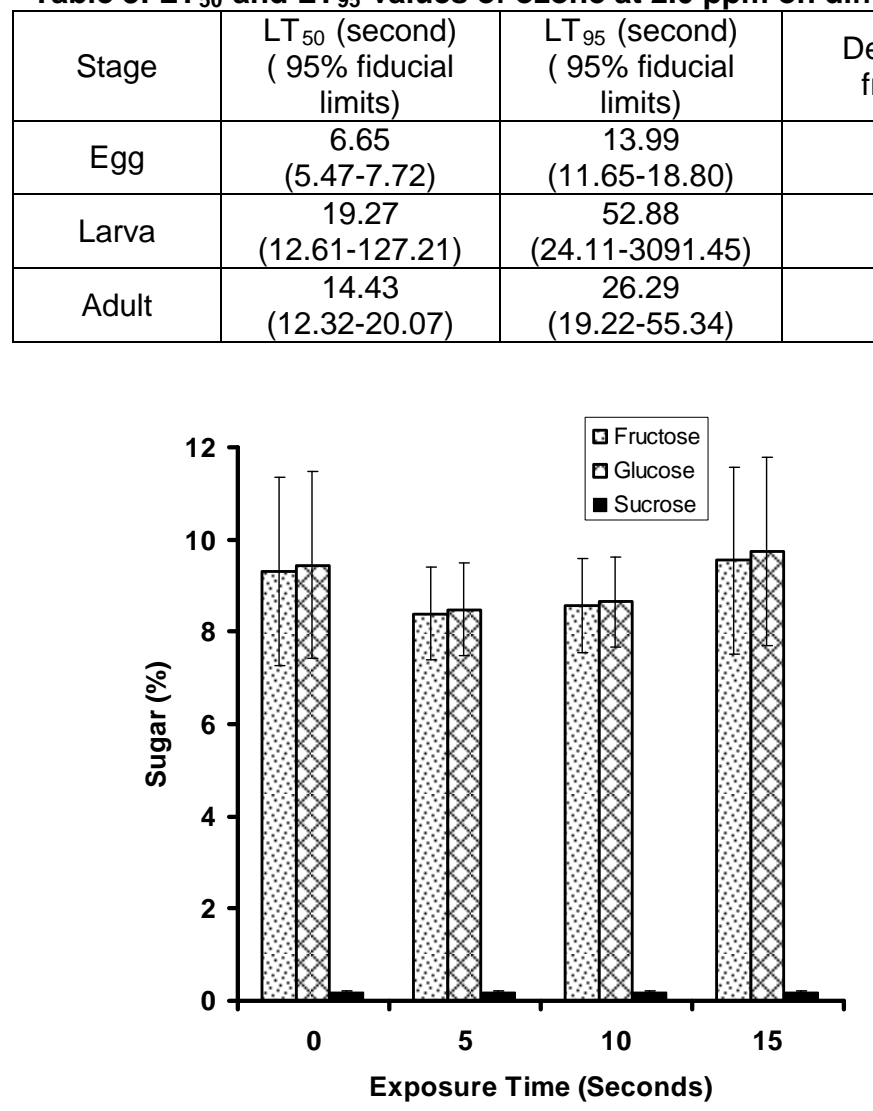

Fig. 5: Sugar profile of dates treated by maximum microwave power for various exposure times. 


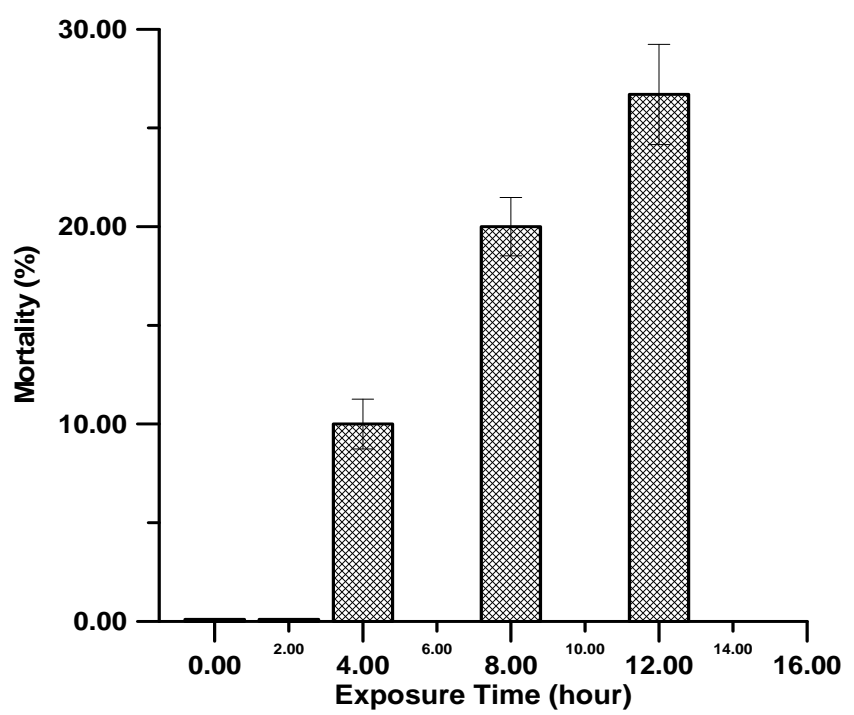

Fig. 7: Effect of $2.0 \mathrm{ppm}$ ozone on larvae of E. cautella at various exposure times.

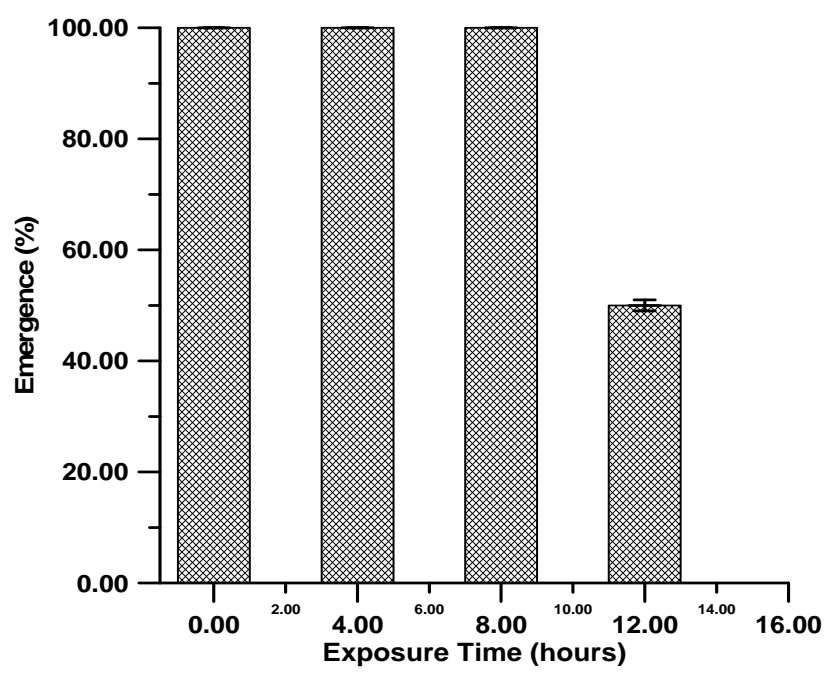

Fig. 8: Effect of $2.0 \mathrm{ppm}$ ozone on pupae of E. cautella at various exposure times.

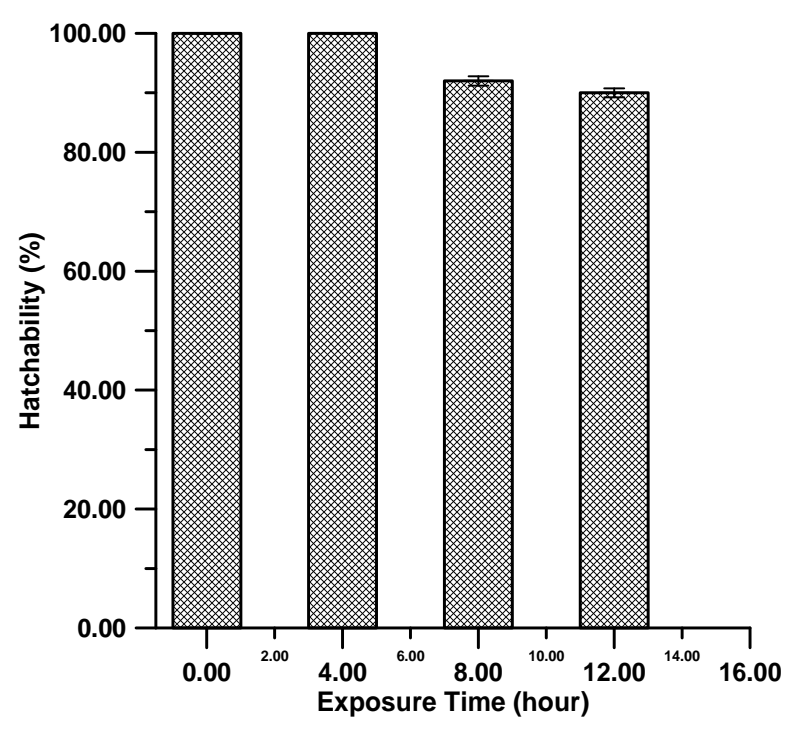

Fig. 9: Effect of $2.0 \mathrm{ppm}$ ozone on eggs of $E$. cautella at various exposure times.

\section{DISCUSSION}

According to our results, multiple microwave power and ozone had proven to be effective against the different developmental stages of $E$. cautella. Five seconds exposure time at various MP up to $60 \%$ had no effect on insect mortality, however by increasing the MP up to $100 \%$, the mortality reached $20 \%$ for larvae and $33 \%$ for adults. When exposure time was increased to 15 seconds with different MP, percent mortality reached $100 \%$ and $80 \%$ at $60 \%$ power with $\mathrm{LT}_{50} 10.5$ and 13.05 seconds and $\mathrm{LC}_{50} 53.76$ and $43.67 \%$ for adults and larvae respectively. These results are partially consistent with that reported by Trandeel (2003), who showed that the required exposure times for $50 \%$ mortality of the two species Oryzaephilus surinamensis and Tribolium castaneum in date by microwave radiation $(2450 \mathrm{MHz})$ were approximately 22, 19 seconds respectively. In addition, the exposure of Sitophilus oryzae adults to microwave radiation for 25 seconds was very effective and gave $100 \%$ mortality; however, 5 sec. exposure time was not significantly different comparing with control (El-Disouky, 2002). Moreover, the influence of microwave application to control $E$. cautella on figs as alternative method for fumigation by heating for 90 seconds in a microwave oven is sufficient to kill the larvae, pupa and eggs of this insect (Baysal et al.,1998). The mechanism of microwave bio-interaction showed that microwave acts as promoting agents in inducing genetic changes in bio-system, could induce different 
physiological effects (Banik et al. 2003). Both microwave and heat treatments led to Tribolium castaneum DNA degradation and the ability of microwave treatment to cause DNA aggregation may suggest a possible mechanism for the enhanced ability of low intensity microwave radiation (LIMR) to cause insect lethality (Lu et al. 2010a). Our results also demonstrated that microwave and ozone had no detrimental effects on protein and sugar profiles isolated from dates treated by microwave at maximum potency up to 15 seconds and by ozone at concentration of $2.0 \mathrm{ppm}$ for $12 \mathrm{~h}$.

These results are in agreement with other investigators who reported that low intensity microwave radiation (LIMR) had a little effect on food quality (Zhao et al. 2007) and wheat flour quality (Vadivambad et al. 2007; Li et al. 2008). By using microwave treatment, it is possible to heat pest insects to lethal temperature while leaving the foodstuff in which they live unaffected or heated to a lesser extent than the insects themselves ( $\mathrm{Lu}$ et al. 2010a).

In our experiments, ozone exhibited less effect against eggs and pupae. Exposing eggs and pupae to $2.0 \mathrm{ppm}$ ozone for 12 hours resulted in $91 \%$ hatchability and $50 \%$ emergence respectively. This could be most likely attributed to the chemical nature of the egg chorion, which could reflect and prevent the ozone to pass through. The possible explanation for the low susceptibility of pupae to ozone, could be due to its latent stage, which is characterized by different physiological properties as compared with other developmental stages in the life cycle of holometabolous insects. There are other explanations of $E$. cautella exhibiting lower mortality with ozone, that the respiratory system of insects consists of a highly branched system of cuticle lined tubes extending throughout the body. Ozone acts as a toxic chemical that can cause oxidative damage of tissues even at low concentrations (Liu et al., 2007). Where, it has been proposed that insects breathe discontinuously to minimize oxidative damage (Hetz and Bradley, 2005). Therefore, changes in the concentration of ozone have the potential to affect the rate of respiration. Lu et al. (2010b), reported that effects of ozone on respiration had two distinct phases. Phase 1 involved lower respiration of the tested adult stored-product Coleopteran under ozone atmosphere. In phase 2, ozone treatment increased the respiration of $S$. oryzae, $R$. dominica, and $T$. castaneum adults when ozone degraded to oxygen. Therefore, the explanations for our results that such insect could get recovery because they may have had high metabolic rates due to an energy intensive induced cellular immune response (Bouwer et al., 2009).

Pure ozone is a toxic, bluish, unstable, potentially explosive gas which is a natural component of the atmosphere. As an oxidizing agent in organic and inorganic reactions, is used in many fields (Kells et al., 2001), such as water purification, bleaching and disinfection of medical appliances as well as to eliminate odours, colours, pesticides, inorganic, and organic compounds. The attractive aspect of ozone is that it decomposes rapidly (in about half an hour in atmospheric conditions) to molecular oxygen without leaving a residue. Therefore ozone can safely be used in the food processing industry (Palou et al., 2002; Forney et al., 2007; Wei et al., 2007). Some studies have been published on its efficacy as a fumigant against pests of stored products (Erdman, 1980; Kells et al., 2001; Sousa et al., 2008). The efficacy of ozone against $T$. castaneum and $T$. confusum has been investigated by mortality of larvae (Erdman, 1980). Maize treated with 50 ppm ozone for 3 days resulted in $92-100 \%$ mortality of adult $T$. castaneum, Sitophilus zeamais and Plodia interpunctella larvae (Kells et al., 2001). The influence of high ozone concentrations on the chemical composition and processing performance of food was studied. Mendez et al. (2002) showed that treatment of grains with $50 \mathrm{ppm}$ ozone for 30 days had no detrimental effect on popping volume of popcorn, fatty acid and amino acid composition and milling characteristic of corn.

In conclusion, the present work has clearly demonstrated that the microwave and ozone had proven to be effective against the different stages of E. cautella. They also showed no detrimental effects on quality of proteins and sugars isolated from treated dates up to 15 seconds at the maximum microwave power and $2.0 \mathrm{ppm}$ ozone for $12 \mathrm{~h}$ respectively. Thus, microwave and ozone, at the experimental application, could be used in integrated management program against insect pests in warehouses as promising alternative candidates to methyl bromide.

\section{ACKNOWLEDGMENTS:}

The authors would like to acknowledge the Ministry of Higher Education, Saudi Arabia for funding the project No. PC-1, through generous financial support to the Date Palm Research Center of Excellence, 
King Faisal University, Hofuf, Saudi Arabia.References:

\section{REFERENCES}

Al-Azab, A.M.A. (2007). Alternative approaches to methyl bromide for controlling Ephestia cautella (Walker) (Lepidoptera: Pyralidae). M. Sc. Thesis, College of Agricultural and Food Science, King Faisal University, Saudi Arabia.

AOAD. Arab Organization for Agricultural Development. (2009). Arab Agricultural Statistics Yearbook, Volume 29 [online]. Available from http://www.aoad.org/Statistical_Yearly_Book_Vol_29.p df [accessed 6 November 2010].

Banik, S., Bandyopadhyay, S., and Ganguly, S. (2003). Bioeffects of microwave - a brief review. Bioresource Technology, 87: 155-159.

Baysal, T., Ural, A., Çakır, M. and Özen, Ç.N. (1998). Microwave application for the control of Dried fig moth. In Proceedings of the first international symposium on fig (24-28 June 1997). Acta Horticulturae, 480: 215220.

Bouwer, G., Nardini, L., Duncan, F.D. (2009). Helicoverpa annigera (Lepidoptera: Noctuidae) larvae that survive sublethal doses of nucleopolyhedrovirus exhibit high metabolic rates. Journal of Insect Physiology, 55: 369374.

Bradford, M.M. (1976). A rapid and sensitive method for the quantitation of microgram quantities of protein utilizing the principle of protein-dye binding. Analytical Biochemistry, 72: 248-254.

Brygidyr, A.M., Rzepecka, M. and McConnell, M.B. (1977). Characterization and drying of tomato paste foam utilizing hot air and microwave energy. Can. Inst. Food Sci. Technol. J. 10: 313-319.

El-Disouky, M. (2002). Efficacy of insecticide formulations and alternative methods against certain insects. Ph.D. Thesis. Faculty of Agriculture, Alexandria University, Eygpt.

Erdman, H.E. (1980). Ozone toxicity during ontogeny of two species of flour beetles, Tribolium confusum and T. castaneum. Environmental Entomology 9: 16-17.

Botes, A. and Zaid, A. (2002). The economic importance of date production and international trade (Chapter III). In Date palm cultivation. Edited by A. Zaid. FAO Plant Production and Protection Paper. 156, Review 1. Available from http://www.fao.org/DOCREP/006/Y4360E/y4360e07.ht $\mathrm{m}$ [accessed 4 October 2010].

Finney, D.J. (1971). Probit Analysis, 3rd Ed, Cambridge University Press, London.
Forney, C.F., Song, J., Hildebrand, P.D., Fan, L., and McRae, K.B. (2007). Interactive effects of ozone and 1-methylcyclopropene on decay resistance and quality of stored carrots. Postharvest Biology and Technology, 45: 341-348.

Hetz, S.K. and Bradley, T.J. (2005). Insects breathe discontinuously to avoid oxygen toxicity. Nature, 433: 516-519.

Isikber, A.A. and Öztekin, S. (2009). Comparison of susceptibility of two stored-product insects, Ephestia kuehniella Zeller and Tribolium confusum du Val to gaseous ozone. Journal of Stored Products Research, 45: 159-164.

Kells, S.A., Mason, L.J., Maire, D.E. and Woloshuk, C.P. (2001). Efficacy and fumigation characteristics of ozone in stored maize. Journal of Stored Products Research, 37: 371-382.

Laemmli, U.K. (1970). Cleavage of Structural Proteins during the Assembly of the Head of Bacteriophage T4. Nature, 227: 680-685.

Li, Y.L., Zhou, J.C., Zhao, S.M. (2008). The influence of heat treatment on the quality of wheat flour. Cereal and Feed industry, 12: 13-19 (in Chinese).

Liu, H.H., Wu, Y.C. and Chen, H.L. (2007). Production of ozone and reactive oxygen species after welding. Archives of Environmental Contamination and Toxicology, 53: 513-518.

Lu, H.H., J.C. Zhou, D. Yan, S.M. Zhao and S.B. Xiong. (2010a). Effects of microwave radiation and conductive heating on Tribolium castaneum microstructure. Micron, 42: 36-41.

Lu, H., Zhou, J., Xiong, S. and Zhao, S. (2010b). Effects of low intensity microwave radiation on Tribolium castaneum physiological and biochemical characteristics and survival. Journal of insect physiology, 56: 1356-1361.

Mendez, F., Maier, D.E., Mason, L.J. and Woloshuk, C.P. (2002). Penetration of ozone into columns of stored grains and effects on chemical composition and processing performance. Journal of Stored Products Research, 39: 33-44.

Palou, L, Crisosto, C.H., Smilanick, J.L, Adaskaveg, J.E. and Zoffoli, J.P. (2002). Effects of continuous 0.3 ppm ozone exposure on decay development and physiological responses of peaches and table grapes in cold storage. Postharvest Biology and Technology, 24: 39-48.

Singh, P. and Moore R.F. (1985). Handbook of insect rearing. Vol. II. Elsevier Science Publishers, Amsterdam.

Sousa, A.H., Faroni, LRD., Guedes, RN.C., Totola, M.R and Urruchi, W.I. (2008). Ozone as a management 
alternative against phosphine-resistant insect pests of stored products. journal of Stored Products Research, 44: 379-385.

Tang, J.; J.N. Ikediala; S. Wang; J.D. Hansen and R.P Cavalieri. (2000). High-temperature-short-time thermal quarantine methods. Postharvest Biology and Technology, 21: 129-145.

Tilton, E.W. and J.H. Brower. (1987). Ionizing radiation for insect control in grain and grain products. Cereal Foods World, 32: 330- 335.

Trandeel, F. (2003). Control of some dried fruit pest's. Master Thesis, Pesticides Department, Faculty of Agriculture, Alexandria University, Egypt.

UNEP. (1999). United Nations Environment Programme, Division of Technology, Industry and Economics, OzonAction Programme, Methyl Bromide Phase-Out Strategies, A Global Compilation of Laws and Regulations. United Nations Publication, ISBN: 92807-1773-1, available from http://www.unep.fr/ozonaction/information/mmcfiles/30 20-e.pdf [accessed 28 October 2010].
Vadivambal, R., Jayas, D.S. and White, N.D.G. (2007). Wheat disinfestations using microwaves energy. Journal of Stored Products Research, 43: 508-514.

Wang, S., J. Tang and R.P. Cavalieri. (2001a). Modeling fruit internal heating rates for hot air and hot water treatments. Postharvest Biology and Technology, 22: 257-270

Wang, S., J.N Ikediala; J.Tang; J.D. Hansen; E. Mitcham; R., Mao and B. Swanson. (2001b). Radio frequency treatments to control codling moth in in-shell walnuts Postharvest Biology and Technology, 22: 29-38.

Wei, K., Zhou, H.D., Zhou, T., and Gong, J.H. (2007). Comparison of aqueous ozone and chlorine as sanitizers in the food processing industry: impact on fresh agricultural produce quality. Ozone-Science and Engineering, 29: 113-120.

Zhao, S. M., Xiong, S.B., Qiu, C.G. and Xu, Y.L. (2007). Effect of microwaves on rice . Journal of Stored Products Research, 43: 496-502. 